\title{
OVERVIEW OF THE LIFESTYLE OF HYPERTENSION PATIENTS
}

\author{
${ }^{1}$ Sri Ramadhan, ${ }^{2}$ Adinda Nurfitriyani, ${ }^{3}$ Eka Silfiani, ${ }^{4}$ Tiara Rahmawati, ${ }^{5}$ Munaya Fauziah \\ Faculty of Public Health, University of Muhammadiyah Jakarta \\ K.H. Ahmad Dahlan State, Cireundeu, Ciputat, Jakarta Selatan, 15419 \\ E-mail: sriramadhan29@gmail.com
}

\begin{abstract}
Hypertension is influenced by several factors such as gender, age, genetics, family history of the disease, excessive salt intake, smoking habits, less than optimal diet (quality and quantity), lack of physical activity, and excessive body weight. The world health organization (WHO) shows that in world data about $39.6 \%$ of people suffer from hypertension. Hypertension is usually experienced by late adults or the elderly. According to Riskesdas, the prevalence of hypertension in Indonesia was $25.8 \%$ in 2007 with age > 18 years. Research conducted in Jakarta shows that the prevalence of hypertension reaches $20 \%$. Researchers are interested in studying the relationship between lifestyle and the incidence of hypertension. This study aims to determine the description of the lifestyle of patients with hypertension. This study uses a qualitative method by collecting data from interviews which are expressed in words or writing. This study is a study conducted on 4 people with hypertension. The time of the research took place in June 2021. The results of the study obtained that lifestyle greatly affects the incidence of hypertension. Physical activity research was obtained from 4 respondents, most respondents rarely do physical activity and most of them consume foods that are high in salt content.
\end{abstract}

Keywords: Hypertension, Lifestyle, Spirituality 
E-ISSN: 2808-5361
Proceeding The First

Muhammadiyah

Internasional- Public Health

and Medicine Conference

\section{INTRODUCTION}

Hypertension is one of the health problems that interfere with the cardiovascular system and can cause death. The primary risk factors that can cause coronary heart disease (CHD), stroke, and heart failure.

Hypertension is influenced by several factors such as lifestyle and diet. Factors that influence include gender, age, genetics, family history of the disease, excessive salt intake, smoking habits, less than optimal eating patterns (quality and quantity), lack of physical activity, and excessive weight.

World health agency World Health Organization (WHO)data shows that around 39.6\% of people suffer from hypertension, hypertension is usually experienced by late adults or the elderly. According to Riskesdas, the prevalence of hypertension in Indonesia was $25.8 \%$ in 2007 with age > 18 years. Research conducted in Jakarta shows that the prevalence of hypertension reaches $20 \%$.

According to research conducted by Meylen et al, stated that there is a significant relationship between lifestyle and the incidence of hypertension in Kolongan Health Center, Kalawat District, North Minahasa Regency.

Based on the data above, researchers are interested in studying the relationship between lifestyle and the incidence of hypertension.

\section{METHODS}

This study aims to determine the description of the lifestyle of patients with hypertension. The type of research used is qualitative research using the participatory observation method. The research was conducted by conducting in-depth interviews. Interviews were conducted through face-to-face questions and answers to obtain information for research purposes.

This study uses a qualitative method by taking data from interviews which are expressed in words or writing. This study is a study conducted on patients with hypertension. And a sample of 4 people was taken. The time of the research took place in June 2021.

4 informants were interviewed in June 2021, sampling was done through face-to-face interviews. Sources of information or informants in this study were people with hypertension. Informants who will conduct in-depth interviews are 4 informants who have a history of hypertension. Informants were selected based on their capacity to explain the objectives of this study.

This study uses two types of data sources, namely primary data and secondary data. Primary data is used exclusively to answer research questions. The author collects the original data through survey methods and observation methods. Secondary data is obtained from data collection techniques that support primary data. This study was obtained from the author's observations and literature research related to this research. 
E-ISSN: 2808-5361 http://e-journal.fkmumj.ac.id/
Proceeding The First

Muhammadiyah

Internasional- Public Health and Medicine Conference

Data validity was done by the triangulation method. This study used data collection through interviews with informants with hypertension.

To maintain the validity of the data, to determine the validity of the data in this study, triangulation was used, namely in-depth interviews. In-depth interview, which is generally a process of obtaining information for research purposes using face-to-face questioning or through communication media between the interviewer and the informant, with or without the use of interview guidelines.

The processing and analysis of qualitative data in this study were carried out at the data transcription stage, and the data was transmitted in written form, without changing, adding, or subtracting the information contained in the notes. Then perform descriptive data analysis to conclude from the data that has been coded the answers of each resource person contained in the table.

\section{RESULTS AND DISCUSSION}

Table 1. Research Results

\begin{tabular}{|c|c|c|c|c|c|}
\hline TOPIC & $\begin{array}{c}\text { MEANING } \\
\text { UNITS }\end{array}$ & CODE & SUBCATEGORY & CATEGORY & THEME \\
\hline $\begin{array}{l}\text { What symptoms } \\
\text { did you feel until } \\
\text { you finally } \\
\text { decided to do a } \\
\text { blood pressure } \\
\text { check? }\end{array}$ & $\begin{array}{l}\text { - There are no } \\
\text { symptoms } \\
\text { because } \\
\text { yesterday the } \\
\text { heart was } \\
\text { checked and } \\
\text { the blood } \\
\text { pressure was } \\
\text { high } \\
\text { Excessive } \\
\text { dizziness and } \\
\text { dark eyes } \\
\text { - I have no } \\
\text { symptoms. At } \\
\text { that time I } \\
\text { wanted the } \\
\text { corona } \\
\text { vaccine when } \\
\text { my blood } \\
\text { health check } \\
\text { was high } \\
\text { Feeling dizzy } \\
\text { like that }\end{array}$ & $\begin{array}{l}\text { No } \\
\text { symptoms } \\
\text { are felt } \\
\text { Feeling } \\
\text { excessive } \\
\text { dizziness }\end{array}$ & $\begin{array}{l}\text { Differences in } \\
\text { hypertension } \\
\text { symptoms }\end{array}$ & $\begin{array}{l}\text { Symptoms of } \\
\text { hypertension }\end{array}$ & $\begin{array}{l}\text { Lifestyle } \\
\text { overview }\end{array}$ \\
\hline $\begin{array}{l}\text { What type of } \\
\text { medication does } \\
\text { the doctor } \\
\text { recommend to } \\
\text { lower blood } \\
\text { pressure? }\end{array}$ & $\begin{array}{l}\text { - Suggest } \\
\text { medicine for } \\
\text { low blood } \\
\text { pressure but I } \\
\text { forget what it's } \\
\text { called }\end{array}$ & $\begin{array}{l}\text { - Suggest low } \\
\text { blood } \\
\text { pressure } \\
\text { - Suggest to } \\
\text { keep the diet }\end{array}$ & $\begin{array}{l}\text { Drug advice from } \\
\text { a doctor }\end{array}$ & $\begin{array}{l}\text { Hypertension } \\
\text { Medication }\end{array}$ & $\begin{array}{l}\text { Lifestyle } \\
\text { overview }\end{array}$ \\
\hline
\end{tabular}




\begin{tabular}{|c|c|c|c|c|c|}
\hline TOPIC & $\begin{array}{c}\text { MEANING } \\
\text { UNITS }\end{array}$ & CODE & SUBCATEGORY & CATEGORY & THEME \\
\hline & $\begin{array}{l}\text { - } \text { The doctor } \\
\text { suggested } \\
\text { taking the } \\
\text { drug } \\
\text { amlodipine } \\
5 \mathrm{mg} \\
\text { - Drugs are not } \\
\text { recommended, } \\
\text { you just have } \\
\text { to keep your } \\
\text { diet } \\
\text { - The doctor } \\
\text { advised me to } \\
\text { take } \\
\text { amlodipine } \\
\text { 5mg }\end{array}$ & & & & \\
\hline $\begin{array}{lr}\text { Have you tried } \\
\text { natural/traditional } \\
\text { ingredients to } \\
\text { lower } \\
\text { pressure? }\end{array}$ & $\begin{array}{l}\text { - Not because } \\
\text { auntie feels } \\
\text { normal } \\
\text { - Yes, } \\
\text { consuming } \\
\text { like boiled } \\
\text { pumpkin and } \\
\text { cucumber } \\
\text { - Yes, I tried it } \\
\text { like eating } \\
\text { cucumber, } \\
\text { eating boiled } \\
\text { pumpkin, } \\
\text { eating star } \\
\text { fruit, then } \\
\text { blending } \\
\text { celery } \\
\text { - Yes, I have } \\
\text { been drinking } \\
\text { boiled water } \\
\text { from bay } \\
\text { leaves and } \\
\text { lemongrass for } \\
\text { the past few } \\
\text { days }\end{array}$ & $\begin{array}{l}\text { - No, because } \\
\text { I don't feel } \\
\text { the need } \\
\text { - Try the } \\
\text { pumpkin and } \\
\text { cucumber } \\
\text { stew } \\
\text { - Try the } \\
\text { cucumber } \\
\text { stew, } \\
\text { pumpkin, eat } \\
\text { star fruit and } \\
\text { celery } \\
\text { blended } \\
\text { - Drink boiled } \\
\text { water of bay } \\
\text { leaves and } \\
\text { lemongrass }\end{array}$ & $\begin{array}{l}\text { Try alternative } \\
\text { medicine }\end{array}$ & $\begin{array}{l}\text { Traditional } \\
\text { medicine }\end{array}$ & $\begin{array}{l}\text { Lifestyle } \\
\text { overview }\end{array}$ \\
\hline $\begin{array}{l}\text { What is the } \\
\text { doctor's advice } \\
\text { for lowering } \\
\text { blood pressure? }\end{array}$ & $\begin{array}{l}\text { - Was told to } \\
\text { come back in } \\
\text { a week for a } \\
\text { check-up } \\
\text { - Change the } \\
\text { pattern of } \\
\text { eating and } \\
\text { sleeping }\end{array}$ & $\begin{array}{l}\text { - Requested } \\
\text { check-up } \\
\text { - Change your } \\
\text { diet and get } \\
\text { enough sleep } \\
\text { - Losing } \\
\text { weight, } \\
\text { reducing }\end{array}$ & Care for yourself & $\begin{array}{l}\text { Maintain } \\
\text { lifestyle }\end{array}$ & $\begin{array}{l}\text { Lifestyle } \\
\text { overview }\end{array}$ \\
\hline
\end{tabular}




\begin{tabular}{|c|c|c|c|c|c|}
\hline TOPIC & $\begin{array}{l}\text { MEANING } \\
\text { UNITS }\end{array}$ & CODE & SUBCATEGORY & CATEGORY & THEME \\
\hline & $\begin{array}{l}\text { enough and } \\
\text { check up } \\
\text { - I was told to } \\
\text { reduce weight, } \\
\text { reduce } \\
\text { coconut milk, } \\
\text { reduce oily } \\
\text { food, reduce } \\
\text { salt, don't eat } \\
\text { meat first, and } \\
\text { regularly } \\
\text { check blood } \\
\text { pressure } \\
\text { Eat less rice, } \\
\text { salt, coconut } \\
\text { milk }\end{array}$ & $\begin{array}{l}\text { coconut milk } \\
\text { and oily } \\
\text { food, salt, } \\
\text { meat, and } \\
\text { being asked } \\
\text { to check up } \\
\text { - Reduce rice, } \\
\text { salt, and } \\
\text { coconut milk }\end{array}$ & & & \\
\hline $\begin{array}{l}\text { After doing the } \\
\text { examination, } \\
\text { have there been } \\
\text { any changes in } \\
\text { diet? }\end{array}$ & $\begin{array}{l}\text { - Usually, eat } \\
\text { dinner every } \\
\text { day now rarely } \\
\text { eat dinner } \\
\text { - Yes, there is } \\
\text { something like } \\
\text { reducing foods } \\
\text { that are high } \\
\text { in salt content } \\
\text { - Yes, here. Eat } \\
\text { fewer } \\
\text { portions, food } \\
\text { is not too salty } \\
\text { - Yes, it's } \\
\text { available now, } \\
\text { so I've started } \\
\text { eating less rice } \\
\text { instead of } \\
\text { potatoes }\end{array}$ & $\begin{array}{l}\text { - Dinner } \\
\text { patterns } \\
\text { change } \\
\text { - Reduce salt } \\
\text { levels } \\
\text { - Portions eat a } \\
\text { little, and not } \\
\text { salty } \\
\text { - Replacing } \\
\text { rice with } \\
\text { potatoes }\end{array}$ & $\begin{array}{l}\text { There is a change } \\
\text { in diet }\end{array}$ & $\begin{array}{l}\text { Maintain } \\
\text { lifestyle }\end{array}$ & $\begin{array}{l}\text { Lifestyle } \\
\text { overview }\end{array}$ \\
\hline
\end{tabular}

After doing the examination, did you pay attention to your weight?

\begin{tabular}{|c|c|c|c|c|}
\hline $\begin{array}{l}\text { Don't pay } \\
\text { attention, } \\
\text { because before } \\
\text { you know you } \\
\text { have high } \\
\text { blood, your } \\
\text { body is } \\
\text { already thin } \\
\text { Yes, I pay } \\
\text { attention, I } \\
\text { like to weigh } \\
\text { my weight } \\
\text { every week } \\
\text { but there is no }\end{array}$ & $\begin{array}{l}\text { Body getting } \\
\text { thin } \\
\text { - No changes } \\
\text { - The pants } \\
\text { you wear are } \\
\text { loose } \\
\text { - Experiencing } \\
\text { changes }\end{array}$ & $\begin{array}{l}\text { There is a change } \\
\text { in weight }\end{array}$ & $\begin{array}{l}\text { Maintain } \\
\text { lifestyle }\end{array}$ & $\begin{array}{l}\text { Lifestyle } \\
\text { overview }\end{array}$ \\
\hline
\end{tabular}




\begin{tabular}{|c|c|c|c|c|c|}
\hline TOPIC & $\begin{array}{c}\text { MEANING } \\
\text { UNITS }\end{array}$ & CODE & SUBCATEGORY & CATEGORY & THEME \\
\hline & $\begin{array}{l}\text { change for BB } \\
\text { - He noticed. I } \\
\text { like to see the } \\
\text { mirror and the } \\
\text { size of the } \\
\text { pants that used } \\
\text { to be tight are } \\
\text { now loose } \\
\text { - Yes, my son } \\
\text { even bought a } \\
\text { scale, so every } \\
\text { morning I } \\
\text { always weigh } \\
\text { myself }\end{array}$ & & & & \\
\hline
\end{tabular}

\begin{tabular}{|c|c|c|c|c|c|}
\hline $\begin{array}{l}\text { After doing the } \\
\text { examination, } \\
\text { have you been } \\
\text { exercising more } \\
\text { often? }\end{array}$ & $\begin{array}{l}\text { - Most wake up } \\
\text { immediately } \\
\text { run to the } \\
\text { bathroom keep } \\
\text { - I exercising. I } \\
\text { happen to } \\
\text { have to go } \\
\text { through } \\
\text { dozens of } \\
\text { stairs at work } \\
\text { - Yes, often. } \\
\text { Monday to } \\
\text { Friday, } \\
\text { usually do an } \\
\text { afternoon } \\
\text { walk, } \\
\text { sometimes a } \\
\text { jog. But if } \\
\text { Saturday, } \\
\text { Sunday } \\
\text { morning, and } \\
\text { evening } \\
\text { No, because } \\
\text { I'm busy at } \\
\text { work so I don't } \\
\text { have time to } \\
\text { exercise }\end{array}$ & $\begin{array}{l}\text { - Not } \\
\text { exercising } \\
\text { - Climbing } \\
\text { stairs while } \\
\text { exercising } \\
\text { - Sports } \\
\text { walking to } \\
\text { jogging } \\
\text { - Not } \\
\text { exercising } \\
\text { because I'm } \\
\text { busy }\end{array}$ & $\begin{array}{l}\text { a change in } \\
\text { lifestyle }\end{array}$ & $\begin{array}{l}\text { Maintain } \\
\text { lifestyle }\end{array}$ & $\begin{array}{l}\text { Lifestyle } \\
\text { overview }\end{array}$ \\
\hline $\begin{array}{l}\text { Was there a } \\
\text { change in blood } \\
\text { pressure when } \\
\text { you had your first } \\
\text { checkup with the } \\
\text { last time you had } \\
\text { your blood }\end{array}$ & $\begin{array}{l}\text { - From normal } \\
\text { blood } \\
\text { pressure, from } \\
\text { the first check, } \\
\text { I suddenly got } \\
\text { high blood } \\
\text { when I wanted }\end{array}$ & 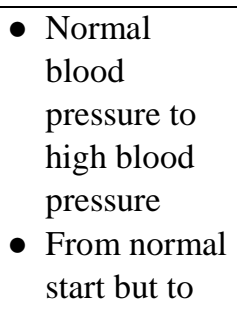 & $\begin{array}{l}\text { There is a change } \\
\text { in blood pressure }\end{array}$ & $\begin{array}{l}\text { Blood } \\
\text { pressure } \\
\text { difference }\end{array}$ & $\begin{array}{l}\text { Lifestyle } \\
\text { overview }\end{array}$ \\
\hline
\end{tabular}




\begin{tabular}{|c|c|c|c|c|c|}
\hline TOPIC & $\begin{array}{l}\text { MEANING } \\
\text { UNITS }\end{array}$ & CODE & SUBCATEGORY & CATEGORY & THEME \\
\hline $\begin{array}{l}\text { pressure } \\
\text { checked? }\end{array}$ & $\begin{array}{l}\text { to record my } \\
\text { heart } \\
\text { - At first, it was } \\
\text { normal when I } \\
\text { wanted to } \\
\text { check the } \\
\text { blood pressure } \\
\text { it went up } \\
\text { - There is a time } \\
\text { when you } \\
\text { want the } \\
\text { vaccine, the } \\
\text { blood pressure } \\
\text { is } 190 / 100 \\
\text { mmHg, the } \\
\text { last check on } \\
\text { Tuesday is } \\
\text { 160/118 } \\
\text { mmHg } \\
\text { Not yet, every } \\
\text { time I check } \\
\text { my blood } \\
\text { pressure is } \\
\text { always high }\end{array}$ & $\begin{array}{l}\text { high } \\
\text { - From the } \\
\text { start, I have } \\
\text { high blood }\end{array}$ & & & \\
\hline $\begin{array}{l}\text { Tell me how your } \\
\text { mother's religion } \\
\text { or belief teaches } \\
\text { you to live a } \\
\text { healthy life and } \\
\text { deal with illness? }\end{array}$ & $\begin{array}{l}\text { - In my } \\
\text { religion, it is } \\
\text { obligatory if } \\
\text { after the dawn } \\
\text { prayer it is } \\
\text { forbidden to } \\
\text { sleep again, } \\
\text { how good it } \\
\text { would be for } \\
\text { us to exercise } \\
\text { In my } \\
\text { religion, I } \\
\text { pray the most } \\
\text { for healing } \\
\text { then after the } \\
\text { morning } \\
\text { prayer I am } \\
\text { not allowed to } \\
\text { sleep } \\
\text { anymore, I } \\
\text { usually recite } \\
\text { the Koran and } \\
\text { then do other } \\
\text { activities } \\
\text { Always try to }\end{array}$ & $\begin{array}{l}\text { It is } \\
\text { forbidden } \\
\text { to sleep } \\
\text { after the } \\
\text { morning } \\
\text { prayer } \\
\text { Pray for } \\
\text { healing }\end{array}$ & $\begin{array}{l}\text { Teachings to be } \\
\text { religious }\end{array}$ & $\begin{array}{l}\text { Religious } \\
\text { perception }\end{array}$ & $\begin{array}{l}\text { Lifestyle } \\
\text { overview }\end{array}$ \\
\hline
\end{tabular}




\begin{tabular}{llllll}
\hline TOPIC & $\begin{array}{l}\text { MEANING } \\
\text { UNITS }\end{array}$ & CODE & SUBCATEGORY & CATEGORY & THEME \\
\hline & pray for his & & & \\
recovery and & & & \\
& always try to & & & \\
& make an effort & & & \\
$\bullet$ & I always carry & & & \\
& out my & & \\
& religious & & & \\
& teachings to & & \\
& maintain & & \\
& health & & \\
& & & \\
& & & \\
\end{tabular}

Hypertension is the medical term for high blood pressure. One of the most influential risk factors for the incidence of heart and blood vessel disease. Usually, hypertension does not show significant symptoms, so it is only realized when organ disorders such as stroke and heart function disorders occur.

There is a significant relationship between lifestyle and hypertension, there is a significant relationship between lifestyle and the incidence of hypertension. The results were obtained from 4 respondents with a lifestyle that greatly affects the incidence of hypertension. Lifestyle is the most important factor that greatly affects health, an unhealthy lifestyle can cause hypertension such as lifestyles such as rarely exercising, feasting(Fadhli, 2018)

Research on physical activity obtained from 4 respondents, most respondents rarely do physical activity, most respondents do physical activity on work holidays and even then only briefly. Activity greatly affects the occurrence of hypertension wherein people with less activity (less movement), but not sick some people often do physical activity. People who do less physical activity tend to have a higher heart rate, so the heart muscle will have to work harder with each contraction. A research journal conducted by(Dkk, 2017) states that having the same results there is an effect of physical activity with hypertension because people who are not active in physical activities tend to have a higher frequency heart rate, the harder the muscle effort to pump blood, the greater the blood pressure imposed on the artery walls so that peripheral resistance causes hypertension.

Food can affect hypertension, from research conducted by 4 respondents, most of them consume foods that are high in salt content. After examining the respondents, it was said that most respondents had hypertension reducing food intake high in salt by replacing boiled foods such as pumpkin and cucumber. The journal states that having the same research results found that food can affect hypertension due to high salt intake. (Kadir, 2019)

Religious belief is an activity that calms and concentrates the mind. The purpose of religion is to calm. This shows that a person's religious beliefs will affect a person's psychological condition, 
based on QS Ar-Rad: 28, namely: people who believe and their hearts become at peace with the remembrance of Allah. Remember, it is only by remembering Allah that the heart becomes at peace(Munawara, 2017).

Spirituality is an intrinsic motivation that can persuade a person to give meaning to life, is a source of strength, and helps a person see the purpose of his life. At the same time, religious beliefs can give a person peace and steadfastness, both spiritual and religious beliefs have a relaxing effect, then the relaxation effect will calm people and balance the body. This condition increases the circulation of oxygen throughout the body, thereby lowering blood pressure in people with hypertension(Aryantini,

2017).

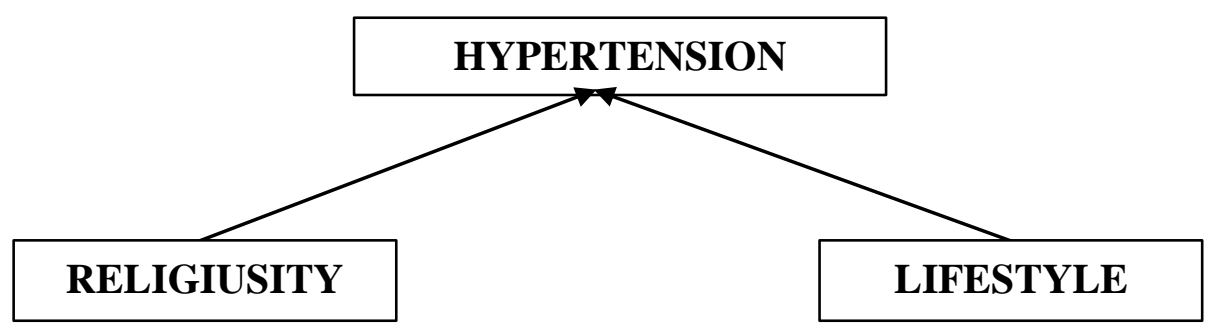

Figure 1. Mind Mapping

\section{CONCLUSION AND SUGGESTIONS}

Based on the results of research that has been done, lifestyle affects hypertension. Due to an unregulated lifestyle can be a potential emergence of hypertension. Ways to prevent hypertension can be by maintaining a healthy diet and exercising regularly and increasing spiritual levels.

Suggestions for people with hypertension to always maintain a lifestyle to recover from the disease. For non-hypertensive patients, they can give constructive motivational words to hypertensive patients to recover from their illness.

\section{REFERENCES}

Ariyantini, MD (2017) 'Relationship of spiritual level and religiosity with blood pressure in hypertensive elderly in the technical service unit of social services tresna werdha (PSTW) Banyuwangi', Thesis.

Etc., H. (2017) 'INFLUENCE OF PHYSICAL ACTIVITY ON THE EVENT OF HYPERTENSION IN EARLY ADULT MEN (18-40 YEARS OLD) IN THE REGION OF BROMO MEDAN PUSKESMAS IN 2017'.

Fadhli (2018) 'RELATED BETWEEN LIFESTYLE AND THE EVENT OF HYPERTENSION IN 
YOUNG ADULTS IN LAMAKAN VILLAGE, KARAMAT DISTRICT, BUOL REGENCY'. Kadir, S. (2019) 'DIETING AND EVENTS OF HYPERTENSION'.

Munawara, DJ (2017) 'The Relationship of Religious Levels to Blood Pressure of Hypertension Patients in Karang Tengah Hamlet, Gamping Sleman Yogyakarta', Nursing, p. xii, 63 pages. 